\title{
EFFECT OF VITAMIN - MINERAL SUPPLEMENTATION IN COMMERCIAL FEED ON THE DIGESTIBILITY COEFFICIENT AND RUMEN FERMENTATION OF BALI CATTLE
}

\author{
P. A. Astawa, I.B.G. Partama, P. Suyadnya and I.N.S. Sutarpa \\ Faculty of Animal Science Udayana University, \\ Jl. PB Sudirman, Denpasar, Bali - Indonesia \\ Corresponding E-mail: ariastawa@yahoo.com
}

Received January 25, 2011; Accepted February 26, 2011

\begin{abstract}
The aim of this study was to find out the influence of vitamin-mineral supplementation on digestibility and rumen fermentation in Bali cattle. The randomized block design with 4 treatments and 4 replications were used in the research. In this study was used 16 Bali cattle with body weight around $295.31 \pm 23.07 \mathrm{~kg}$. Rations used in the treatments were Treatment A (control): rice straw ad libitum plus commercial feed; Treatment B: Treatment A ration plus $0.2 \%$ vitamin-mineral in commercial feed; Treatment $\mathrm{C}$ : Treatment $\mathrm{A}$ ration plus $0.3 \%$ vitamin-mineral in commercial feed, and Treatment $\mathrm{D}$ : Treatment A ration plus $0.4 \%$ vitamin-mineral in commercial feed. Parameters measured were nutrient digestibility, rumen metabolites and urinary allantoin. The results showed that supplementation of vitamin-mineral at $0.2-0.4 \%$ in commercial feed did not increase the digestibility of dry matter, organic matter, crude protein and crude fiber, except for dry matter and organic matter digestibilities at $0.2 \%$ supplementation $(\mathrm{p}<0.05)$. However, the vitamin-mineral supplementation increased concentrations of partial VFA and ammonia as well as for methane gas production, except for VFA and ammonia at $0.4 \%$ level. Vitamin-mineral supplementation at $0.2-0.4 \%$ level did not affected $\mathrm{pH}$ value of rumen fluid and urinary allantoin.
\end{abstract}

Keywords: Bali cattle, Digestibility coefficient, Rumen fermentation, Urinary allantoin, Vitaminmineral supplementation

\section{INTRODUCTION}

The high demand of beef is an opportunity and a challenge. The steps to anticipate the decreasing population of Bali cattle can be done by increasing its productivity through feeding improvement. Bali cattle's growth depends on nutrients quality contained in feedstuffs. High value forages may support the nutrient needed by the Bali cattle, but these availability are very limited especially in Bali. Rice straw is an agricultural waste and its availability is abundant, but up to now its utilization is still limited (Syamsu et al., 2007). The rice straw production reached 5.53 ton dry matter per ha (BPS Bali Province, 2007). In terms of nutrients, rice straw contains crude protein $4.33 \%$ and crude fiber $30.85 \%$ (Utomo, 2005).

In fact, the rice straw is lack of nutrient and could be overcome by providing additional feed. The use of rice straw as the basal diet, even combined with commercial feed for Bali cattle, needs supplementation of vitamin-mineral mix to enrich the nutrients such as vitamins $\mathrm{A}, \mathrm{E}$ and minerals that are damaged during the manufacturing process, storage and the distribution of feed (Parakkasi, 1999). Multivitamin and mineral supplementation could improve the productivity especially on body weight gain as reported by Partama (2006) that Bali cattle given rice straw and commercial feed at $2.5 \%$ of body weight supplemented by $0.2 \mathrm{~kg}$ vitamin-mineral increased the body weight gain by $20 \%$. However, the effect of multivitamin and mineral supplementation on microbial protein synthesis in Bali cattle is still lacking, and therefore need to be studied.

The objective of the study was to find out the influence of vitamin-mineral supplementation on digestibility and rumen fermentation in Bali cattle.

\section{MATERIALS AND METHODS}

\section{Animals and Design}

The research was conducted at the Beef 
Cattle Experimental Station of Animal Husbandry, Fisheries and Maritime Affairs, Gianyar regency, Bali, for three months using sixteen Bali cattle (Bos sondaicus) with body weight (BW) around $295.31 \pm 23.07 \mathrm{~kg}$. The cattle were grouped based on $\mathrm{BW}$ and were grouped into four groups for feeding treatments. The average of the BW on each group of A, B, C and D were 273.5, 294.0, 304.5 and $310.0 \mathrm{~kg}$, respectively. Experimental design used in this study was Randomized Block Design with four treatments and four groups as replication, so there were 16 experimental units.

\section{Feeding Treatments}

The cattle allowed the rations consisted of rice straw ad libitum and commercial feed at 2.5\% of $\mathrm{BW}$ plus vitamin-mineral. The rations were formulated to fulfill or exceed the cattle requirement based on NRC standard (1976). The four feeding treatments were,

1. Treatment A: Rice straw ad libitum plus commercial feed, were given at $2.5 \% \mathrm{BW}$

2. Treatment B: Feeding Treatment A plus $0.2 \%$ vitamin-mineral in commercial feed

3. Treatment C: Feeding Treatment A plus $0.3 \%$ vitamin-mineral in commercial feed

4. Treatment D: Feeding Treatment A plus $0.4 \%$ vitamin-mineral in commercial feed

The chemical compositions of rice straw and commercial feeds as well as formulated rations for feeding treatments are shown in Table 1 and 2.

\section{Digestibility and Rumen Parameters}

Total collection methods to determine nutrients digestibility and urinary Allantoin were carried out by collecting feeds, feces and urine for 7 days on week 11 of feeding treatments period. Nutrients digestibility was calculated according to AOAC (1990).

Nutrients digestibility coefficient $(\%)=$

$$
\frac{\text { Nutrients consumed - nutrients in feces }}{\text { nutrients consumed }} \times 100 \%
$$

Rumen parameters, such as volatile fatty acids (VFA) and ammonia were measured by collecting rumen's fluid which was performed on the day after total collections and at 4 hours after feeding time. The VFA concentration of rumen fluid partial (acetic, propionic and butyric acid) was calculated with formula below:

$$
\text { Partial VFA }(\mathrm{mM})=
$$

\footnotetext{
High sample $x$ concentration of standards
}

Ammonia concentration of rumen fluid was determined using Phenolhypochloride (American Society of Limnology, 1969). This method was based on the color reaction which was determined by the amount of ammonia. Methane production was calculated using the formula of Orskov and Ryle (1990), as follow:

Methane $(\mathrm{mM})=0.5$ Acetate -0.25 propionic +0.5 butyric

The $\mathrm{pH}$ of rumen fluid was measured by a $\mathrm{pH}$ meter, while the protozoa population was measured by the method of Methylgreen Formalin Saline, (Ogimoto and Imai, 1981).

Amount of protozoa population $($ cell $/ \mathrm{ml})=$

$$
\frac{\mathrm{n} \times \mathrm{p} \times \mathrm{Fp}}{\mathrm{A}}
$$

where

$\mathrm{n}=$ The number of protozoa in room count

$\mathrm{p}=10^{4}$

$\mathrm{Fp}=$ Dilution factor

$\mathrm{A}=$ The number of boxes counted

The level of allantoin in urine was measured by the method of Matsumoto et al. (1995), and was calculated using the following formula:

Level of allantoin $=$

$$
\frac{\text { Allantoin standard }}{\text { Allantoin sample }} \times \frac{100}{5}(\mathrm{mg} / 100 \mathrm{ml})
$$

\section{Statistical Analysis}

All data were analyzed using an analysis of variance (ANOVA) and were tested using Duncan's New Multiple Range Test to compare the significant differences between treatment means (Steel and Torrie, 1991).

\section{RESULTS AND DISCUSSION}

\section{Nutrient Digestibility Coefficients}

The coefficients of nutrients digestibility in four feeding treatments are presented in Table 3. The results showed that vitamin-mineral supplementation at $0.2 \%$ in the basal ration containing commercial feed and rice straw increased dry matter digestibility $(\mathrm{p}<0.05)$, but no effect was found in other levels although numerically tended to increase. Similar results were found in organic matter digestibility. These phenomena indicated that digestibility can be maximized with the addition of precursor nutrients such as vitamins, minerals, amino acids, 
Tabel 1. Nutrients Content of Commercial Feeds and Rice Straw

\begin{tabular}{lcc}
\hline Nutrient Content & Commercial Feed & Rice Straw \\
\hline Dry matter (\%) & 84.74 & 87.00 \\
Organic matter (\%) & 80.53 & 75.00 \\
Crude protein (\%) & 14.89 & 4.00 \\
Crude fiber (\%) & 23.92 & 33.00
\end{tabular}

Table 2. Composition of Feedstuffs and Chemical Composition of Rations for Feeding Treatments

\begin{tabular}{|c|c|c|c|c|}
\hline & \multicolumn{4}{|c|}{ Treatment } \\
\hline & A & B & $\mathrm{C}$ & $\mathrm{D}$ \\
\hline \multicolumn{5}{|l|}{ Ration Composition } \\
\hline Commercial Feed (kg) & 100.00 & 99.80 & 99.70 & 99.60 \\
\hline Vitamin-Mineral (kg) & 0.00 & .0 .20 & 0.30 & 0.40 \\
\hline Rice straw (kg) & ad libitum & ad libitum & ad libitum & ad libitum \\
\hline Total $(\mathrm{kg})$ & 100.00 & 100.00 & 100.00 & 100.00 \\
\hline \multicolumn{5}{|l|}{ Nutrients content } \\
\hline Dry matter $(\%)$ & 85.87 & 85.87 & 85.87 & 85.87 \\
\hline Organic matter (\%) & 77.76 & 77.76 & 77.76 & 77.76 \\
\hline Crude protein $(\%)$ & 9.45 & 9.45 & 9.45 & 9.45 \\
\hline Crude fiber $(\%)$ & 25.46 & 25.46 & 25.46 & 25.46 \\
\hline $\mathrm{Zn}(\mathrm{ppm})$ & 45.09 & 85.09 & 105.09 & 125.09 \\
\hline $\mathrm{S}(\mathrm{ppm})$ & 685.50 & 02.09 & 711.10 & 719.64 \\
\hline
\end{tabular}

and readyly available energy (fermentable carbohydrates) in the rations. According to Cakra et al. (2008), the addition of minerals like $\mathrm{Ca}, \mathrm{P}, \mathrm{S}$ and $\mathrm{Zn}$ can improve digestibility coefficients of dry matter, organic matter and nutrient.

Crude protein digestibility coefficient (Table 3) showed not significant different $(p>0.05)$ among the four treatments. This indicated that vitamin-mineral supplementation up to $0.4 \%$ in the commercial diet gave no significant influence to the proteolytic process in the rumen that digests proteins into the rumen. This findings was in contrast with the report of Karsil et al. (2001) that the concentration of vitamins ( $A$ and $E$ ), and minerals ( $\mathrm{Ca}, \mathrm{P}, \mathrm{S}$ and $\mathrm{Zn}$ ) contribute to the efficiency of protein synthesis. Similar result was found in crude fiber digestibility although numerically there was a tendency to increase with the provision of vitamin-mineral. The finding on crude fiber digestibility was slightly supporting the report of Bidura (2005) who claimed that digestion rate of fiber in ruminant is linear to feed quality.

\section{Rumen Metabolites and Allantoin Urine}

The effect of vitamin-mineral supplementation on VFA and ammonia rumen is shown in Table 4. Acetic and butyric acids are the end product of the fiber fermentation in the rumen. In this study the concentration of acetic acid in treatment $B, C$ and D was higher $(p<0.05)$ than that in the treatment $\mathrm{A}$, and this was thought that the level of vitamin-mineral supplementation in commercial rations have fulfilled all the needs of mineral such as $\mathrm{Zn}, \mathrm{S}$, vitamin $\mathrm{A}$ and $\mathrm{E}$. This opinion is supported by Bal and Ozturk (2006) statement that the macro minerals $(\mathrm{P}, \mathrm{Ca}$ and $\mathrm{Mg})$, micro minerals ( $\mathrm{Cu}, \mathrm{Co}, \mathrm{Zn}, \mathrm{Mn}$ and $\mathrm{S}$ ) and vitamins especially vitamins $\mathrm{A}$ and $\mathrm{E}$ played an important role in protein synthesis of rumen microbes, feed degradation and various microbial enzyme activator. 
Table 3. Nutrients Digestibility Coefficients

\begin{tabular}{llllc}
\hline \multirow{2}{*}{ Digestibility coefficients } & \multicolumn{4}{c}{ Treatment } \\
\cline { 2 - 5 } & A & B & C & D \\
\hline Dry matter digestibility (\%) & $60.44^{\mathrm{a}}$ & $79.08^{\mathrm{b}}$ & $66.92^{\mathrm{a}}$ & $65.74^{\mathrm{a}}$ \\
Organic matter digestibility (\%) & $52.73^{\mathrm{a}}$ & $61.82^{\mathrm{b}}$ & $59.84^{\mathrm{a}}$ & $52.98^{\mathrm{a}}$ \\
Crude protein digestibility (\%) & 57.99 & 68.39 & 67.33 & 67.22 \\
Crude fiber digestibility (\%) & 66.39 & 67.40 & 67.96 & 66.64 \\
\hline
\end{tabular}

Values with different superscript in the same row are significantly different $(\mathrm{p}<0.05)$

Table 4. Rumen Metabolites and Allantoin

\begin{tabular}{|c|c|c|c|c|}
\hline \multirow{2}{*}{ Variables of partial VFA } & \multicolumn{4}{|c|}{ Treatment } \\
\hline & A & B & $\mathrm{C}$ & D \\
\hline Acetic acid concentration (mM) & $26.92^{\mathrm{a}}$ & $50.79^{\mathrm{c}}$ & $48.93^{b}$ & $47.56^{\mathrm{b}}$ \\
\hline Propionic acid concentration (mM) & $24.42^{\mathrm{a}}$ & $34.55^{\mathrm{c}}$ & $32.81^{\mathrm{b}}$ & $31.83^{\mathrm{b}}$ \\
\hline Butyric acid concentration (mM) & $18.83^{\mathrm{a}}$ & $26.65^{\mathrm{c}}$ & $22.53^{b}$ & $20.42^{\mathrm{b}}$ \\
\hline Partial VFA concentration (mM) & $70.17^{\mathrm{a}}$ & $111.89^{\mathrm{c}}$ & $104.27^{\mathrm{b}}$ & $99.81^{\mathrm{b}}$ \\
\hline Ammonia concentration (mM) & $3.21^{\mathrm{a}}$ & $9.46^{\mathrm{c}}$ & $4.39^{\mathrm{b}}$ & $3.39^{\mathrm{a}}$ \\
\hline Methane gas production (mM) & $2.86^{\mathrm{a}}$ & $8.00^{\mathrm{c}}$ & $6.39^{\mathrm{b}}$ & $3.82^{\mathrm{a}}$ \\
\hline Rumen fluid $\mathrm{pH}$ value of & 6.27 & 6.41 & 6.53 & 6.63 \\
\hline Population Protozoa (x $10^{5}$ cell $/ \mathrm{ml}$ ) & 3.67 & 4.41 & 4.42 & 4.75 \\
\hline Allantoin urine (mM) & 4.43 & 5.83 & 4.90 & 4.73 \\
\hline
\end{tabular}

Values with different superscript in the same row are significantly different $(p<0.05)$

The propionic acid concentration obtained in treatment $\mathrm{B}, \mathrm{C}$, and $\mathrm{D}$ was higher $(\mathrm{p}<0.05)$ than that in treatment $\mathrm{A}$, while the highest was found in treatment B. It showed that the level of supplementation of $0.2 \%$ has complied with all the nutrients precursor of rumen required for maximum microbial activity in digesting carbohydrates including fermentable carbohydrates (sugars and starches) entered the rumen. Propionic acid is the main result of carbohydrates (sugars and starches) fermentation in the rumen which important to rumen microbial growth and activity (Parakkasi, 1999).

VFA total concentration obtained (acetic, propionic, and butyric) on each treatment showed that supplementation with vitamin and mineral in commercial diet can improve rumen microbial activity in the metabolism of carbohydrates and protein in the rumen. This was supported by the digestibility coefficient in treatment B, C and D which was tended to be higher than that in treatment A. According to the study of Witariadi et al. (2010), the high digestibility of dry matter causes higher rumen metabolism. This study showed the digestibility of dry matter in treatment $\mathrm{B}$ was the highest among those four treatments so that the rumen fermentation process would be more efficient. The VFA produced in the rumen will increase and in turn will lead more nutrient availability for microbes and animals.

The concentration of ammonia resulted in treatment $\mathrm{B}$, and $\mathrm{C}$ was found higher $(\mathrm{P}<0.05)$ than that in treatment A (Table 4) while treatment $\mathrm{B}$ showed the highest among the treatments, being 
$9.46 \mathrm{mM}$. This study showed that giving vitaminmineral could improve protein digestibility (Table 3) which was needed to provide ammonia for rumen microbial growth. Moreover, Khampa et al. (2006) stated that ammonia (N-NH3), carbon dioxide $(\mathrm{CO} 2)$ and methane $(\mathrm{CH} 4)$ in the rumen are used to synthesize microbial cells. It has been explained also that the ammonia contained on the rumen fluid is an indicator of protein quality for the growth of livestock and rumen microbial.

The $\mathrm{pH}$ value obtained on each treatment showed no significant difference $(\mathrm{P}<0.05)$ with $\mathrm{pH}$ ranged of $6.27-6.63$. The increment of $\mathrm{pH}$ on each treatment was caused by the presence of mineral through supplementation of vitaminmineral. The presence of $\mathrm{Zn}$ in the feeding treatment may activate the carbonic anhydrase enzyme which one of its functions is to maintain acid-base balance of rumen fluid in normal $\mathrm{pH}$ ranged at 5.5-7.2, as stated by Owen and Goetsch (1998)

Protozoa population in all feeding treatments was found similar $(p>0.05)$. It indicated that vitamin mineral supplementation has no effect on protozoa population, although numerically there was a tendency that vitamin-mineral supplementation in feeding $\mathrm{B}, \mathrm{C}$, and $\mathrm{D}$ give 0.7 $1.1 \times 10^{5}$ cell $/ \mathrm{ml}$ higher than in feeding A. This tendency is presumably because of the influence of the vitamin-mineral addition especially $\mathrm{Zn}$ and $\mathrm{S}$ in the ration. The presence of $\mathrm{Zn}$ minerals in the rumen will increase microbial protein synthesis through the activation of microbial enzymes, whereas the presence of mineral $\mathrm{S}$ in the rumen can be used as a component of sulfur amino acid by rumen microbes that was in agree with the report of Karma (2005). The presence of $\mathrm{Zn}$ minerals in the rumen will also stimulate growth of rumen protozoa because $\mathrm{Zn}$ can easily penetrate protozoa and was utilized in the body for growth.

The excretion of urinary allantoin is shown in Table 4. Urinary allantoin was found similar among the treatments, indicated that vitaminmineral supplementation has no effect on microbial synthesis. However, the vitaminmineral supplementation tended to lift urinary allantoin by $0.3-1.4 \mathrm{mM}$, if compared to the control feeding. Total excretion of allantoin in urine is representation of bacteria's population growth in the rumen. Increasing excretion of allantoin is an indicator of the improving utilization of microbial protein by the animal, because allantoin is a derivative of the purine nucleic acid which is mainly derived from microbes (Wanapat et al., 2003). The higher allantoin levels, the higher crude protein digested as the result.

\section{CONCLUSION}

The vitamin-mineral supplementation on rice straw and commercial feed increased the digestibility coefficient of dry matter and organic matter, partial VFA and ammonia concentration as well as methane gas production. However, the vitamin-mineral supplementation has no effect on digestibility coefficient of crude protein and crude fiber, and $\mathrm{pH}$ rumen. This study suggested that supplementation of vitamin-mineral at $0.2 \%$ is the best level to increase the feed utilization in Bali cattle.

\section{ACKNOWLEDGMENT}

The authors thank to the Head of Beef cattle Experimental Station, Animal Husbandry, Fisheries and Maritime Affairs, Gianyar regency for providing the research facility.

\section{REFERENCES}

A.O.A.C. 1990. Official Method of Analysis. 13th Ed. Association of Oficial Analysis Chemist, Washington, DC.

American Society Limnnologi. 1969. Oceanography INC. $14: 799-801$

Bal. M.A. and D. Ozturk. 2006. Effects of sulfur containing supplements on ruminal fermentation and microbial protein synthesis research. J. Anim. Vet. Sci. 1(1):33-36

Bidura, I.G.N.G. 2005. Bioteknologi Pakan dan Aplikasi. Buku Ajar Fakultas Peternakan Universitas Udayana. Penerbit Universitas Udayana, Denpasar.

BPS Propinsi Bali. 2007. Bali Dalam Angka Biro Pusat Statistik Propinsi Bali, Denpasar

Cakra I G.L.O., N.W. Siti and I.M. Mudita. 2008. Koefisien cerna bahan kering dan nutrien ransum kambing peranakan etawah yang diberi hijauan dengan konsentrat molamik. Majalah Ilmiah Peternakan Universitas Udayana. 11(1):12-17

Kampha, S. and M. Wanapat. 2006. Influences of energy sources and level on ruminal fermentation supplementation and microbial protein synthesis in dairy stress. J. Nutr. Vet. Sci. 5(4) :294-300 
Kamra, D.N. 2005. Rumen Microbial Ecosystem. Special Section: Microbial Diversity Current Sciences. 89 (1) : 124-135.

Karsil, M.A. and J.R. Russell. 2001. Effect of some dietary factors on ruminal microbial protein synthesis. Turk. Vet. J. Anim Sci. 25(1):681-686.

Matsumoto, M., H. Sato, A. Watanabe, E. Tsuneishi, S. Hanasaka, and K. Hodate. 1995. Allantoin Kessho noudo no sokuteiho no kaiyo. Chikusan Kenkyu houkoku. 9(2): 27-28 (in Japanese).

NRC. 1976. Nutrient Requirements of Beef Cattle. National Academy of Science. Washington, DC. USA.

Ogimoto. K. and S. Imai. 1981. Atlas of Rumen Microbiology. Japan Scientific Societies Press, Tokyo

Orskov, E.R, and M.Ryle. 1990. Capacity of digestion and effects of composition of absorbed nutrient on animal metabolism. J. Anim. Sci. 4(6):600-606

Owen, F.N and A. L. Goetsch. 1988. Rumen Fermentation, pp. 145-171 In: D.C. Church Ed. The Ruminant Animal Digestive Physiology and Nutrition. A. Reston Book. Prentice Hall, New Jersey

Parrakkasi, A. 1999. Ilmu Nutrisi dan Makanan Ternak Ruminansia. Gadjah Mada University Press, Yogyakarta

Partama, I.B.G. 2005. Optimalisasi pemanfaatan jerami padi sebagai pakan dasar sapi Bali penggemukan melalui perlakuan amoniasi dan bifermentasi mikroba. Proseding Seminar Nasinal BPTP Bali. Denpasar-Bali., 28 September 2005. Page 56-59

Steel, R.G.D. and J. H. Torrie. 1990. Principles and Procedures of Statistics. Second Edition. McGraw-Hill Book Company Inc., New York

Syamsu, J.A., L.A. Sofyan, K.G. Mudikdjo and E.G. Said. 2007. Power Support Agricultural Waste as Ruminant Feed Resources. Wartazoa. 24(3):43-45.

Utomo, R. 2005. Suplementasi Campuran Dedak Halus dan Tepung Daun Lantoro pada Jerami padi sebagai Pakan Basal terhadap Sintesa Protein Mikroba Rumen Sapi Peranakan Ogole. Proceeding Seminar AINI V. Universitas Brawijaya Malang. Page 25-29

Wanapat, M. and S. Khampa. 2007. Effect of level suplementation of concentrat containing high levels of cassava chiphon rumen ecology, microbial $\mathrm{N}$ supply and digestibility of nutrients in beef catle. Asian-Aust. J. Anim.Sci., 20 (1):78-81.

Witariadi. N.M, I.K. M. Budiasa, E. Puspani and I.G.L.O. Cakra. 2010. Pengaruh tepung daun gamal dan daun kelor dalam urea Cassava Block (Cub) terhadap kecernaan, kadar VFA dan NH3 In-Vitro. Majalah Ilmiah Peternakan Udayana. 13(1):25-30. 